Our Nature (2011) 9: 119-127

\title{
Mammalian Diversity of Degraded Forest Habitats around Assam University Campus, Cachar, Assam, India, with Notes on Conservation Status
}

\author{
K. Mazumdar ${ }^{* *}$, R. Soud ${ }^{2}$ and A. Gupta ${ }^{3}$ \\ ${ }^{1}$ WWF-India, Western Arunachal Landscape Programme (WAL), Parvati Nagar, Tezpur, Assam, India-784 001 \\ ${ }^{2}$ Department of Humanities and Social Science, Indian Institute of Technology Guwahati, \\ North Guwahati, Assam, India-781039 \\ ${ }^{3}$ Department of Ecology and Environmental Science, Assam University, Silchar, Assam, India-788011 \\ ${ }^{*}$ E-mail: kripaljyoti@gmail.com
}

Received: 23.08.2011, Accepted: 24.12.2011

\begin{abstract}
s
Barak valley in South Assam remains poorly investigated in terms of faunal diversity, especially mammals. This paper inventories 19 species of mammals belonging to 14 families in the degraded forests of Assam University Campus, Silchar, Assam and those maintained by the tea gardens of this area. Of these, three are in the IUCN endangered (EN) and two in vulnerable (VU) categories. The threats faced and conservation priorities are also discussed.
\end{abstract}

Key words: Mammalian diversity, Barak valley, conservation threats, Assam University, degraded forest.

\section{Introduction}

The northeastern region of India, mammalian diversity comprising 193 comprising the states of Arunachal Pradesh, Assam, Manipur, Meghalaya, Mizoram, Nagaland, Sikkim, and Tripura, can be physiographically divided into Eastern Himalaya (Sikkim and Arunachal Pradesh), Northeastern Hills (Meghalaya Plateau, Patkai-Naga Hills and Lushai Hills), and Brahmaputra and Barak Valley plains. Situated at the confluence of the IndoMalayan and Palearctic biogeographic realms, the region contains a profusion of habitats characterized by diverse biota. India harbours a total of 417 species of mammals belonging to 48 families (Nameer, 2000, 2008), of which the northeastern region accounts for 54\% of threatened mammals found in the country (Choudhury, 2006). Assam has a rich

species of mammals belonging to 32 families, thereby representing about $60 \%$ of the country's mammalian diversity (Choudhury, 1997). Assam is located in the transitional zone between the Indian and the Indo-chinese sub-regions where many Indian species have their easternmost limit (e.g., Axis axis) while several other Indochinese species have their westernmost limit of distribution (e.g., Tupaia belangeri).

Faunal inventorying is one of the important tasks for precise taxon-specific and area-specific conservation efforts. Its relevance increases manifold in the light of conspicuous dearth of information about the biodiversity profile of the existing protected area network within the country (Srinivasulu et al., 2004). The Barak valley 
K. Mazumdar, R. Soud and A. Gupta /Our Nature (2011) 9:119-127

in southern Assam, covering an area of $6922 \mathrm{~km}^{2}$, has the North Cachar Hills district and the state of Meghalaya to its north; Manipur to the east; Mizoram to the south; and Tripura and the Sylhet district of Bangladesh to the west. The valley has an undulating topography characterized by low hills interspersed within wide floodplains and low-lying waterlogged areas locally called beels. Significant contributions are lacking on the mammalian diversity of Barak valley, although it has the Borail Wildlife Sanctuary in its north, and the Inner Line Reserve Forest, which is one of the largest reserve forests of the state of Assam covering more than $1000 \mathrm{~km}^{2}$ area, in its southern fringes. The hills of Dargakona, about $20 \mathrm{~km}$ south of Silchar, the district headquarters of Cachar district, where the campus of Assam (Central) University is located, was once covered with dense forest dominated by Artocarpus chama that was almost contiguous with those of the Inner Line Reserve Forest. The University Campus still has patches of degraded forest which is home to several mammalian species that have been inventoried in the present paper.

\section{Materials and methods \\ Study area}

The $c 600$ acre Assam University (AUS) Campus comprises low hills at an elevation of 40-60 m MSL. It has around 150 acres of forest that is contiguous with another 100odd acres of mixed deciduous forest belonging to the Silcoorie (Dargakona) Tea Estate. While the southern part of the University campus is adjacent to the flood plain of the Chatla Haor, its western margin extends to the home gardens and community forests of nearby Irongmara village. The area experiences a warm, humid climate having a mean annual rainfall of $2660 \mathrm{~mm}$, most of which is received during the southwest monsoon season (May to September). The mean maximum temperature ranges from $25.4^{\circ} \mathrm{C}$ (January) to $32.6^{\circ} \mathrm{C}$ (August) and the mean minimum temperature from $11^{\circ} \mathrm{C}$ (January) to $25^{\circ} \mathrm{C}$ (August) (Das and Das, 2005).

The vegetation around the University campus represents a secondary succession status with different degrees of disturbance. The vegetation is dominated by Artocarpus chama and Tetrameles nudiflora comprising the top layer; Ficus sp., Artocarpus lakoocha and others in the middle layer; and Neohouzeana dullooa and saplings of Goniothalamus, Cyclostomes and Mimosa himalayana in the lower. Undergrowth is dominated by Desmodium sp., saplings of Calamus guruba. Daemonorops jenkinsianus, Homanolena sp and seedlings of Artocarpus chama besides other plant species. Disturbance in the vegetation has resulted in the growth of early successional plants like Cromelina sp., Combretum sp., Melastoma malabathricum, Macaranga sp., etc. Climbers are represented by Mikenia micrantha, Ipomea sp. and scattered plants of Pandanus sp., Licuala peltata, etc. intermixed with these secondary successional plants. On more degraded sites the vegetation is represented by grass species like Chrysopogon sp. mixed with Desmodium triflorum, Borreria hispida and Mimosa pudica. Characteristic features of tropical forests like the presence of buttresses on the trees, dominance of epiphytes (ferns and orchids) strangling habit of the trees are observed in the tree species of the University Campus (Dutta et al., 1998).

The study area was categorized into four habitat types- Open Forest (OF), Tea 
K. Mazumdar, R. Soud and A. Gupta /Our Nature (2011) 9:119-127

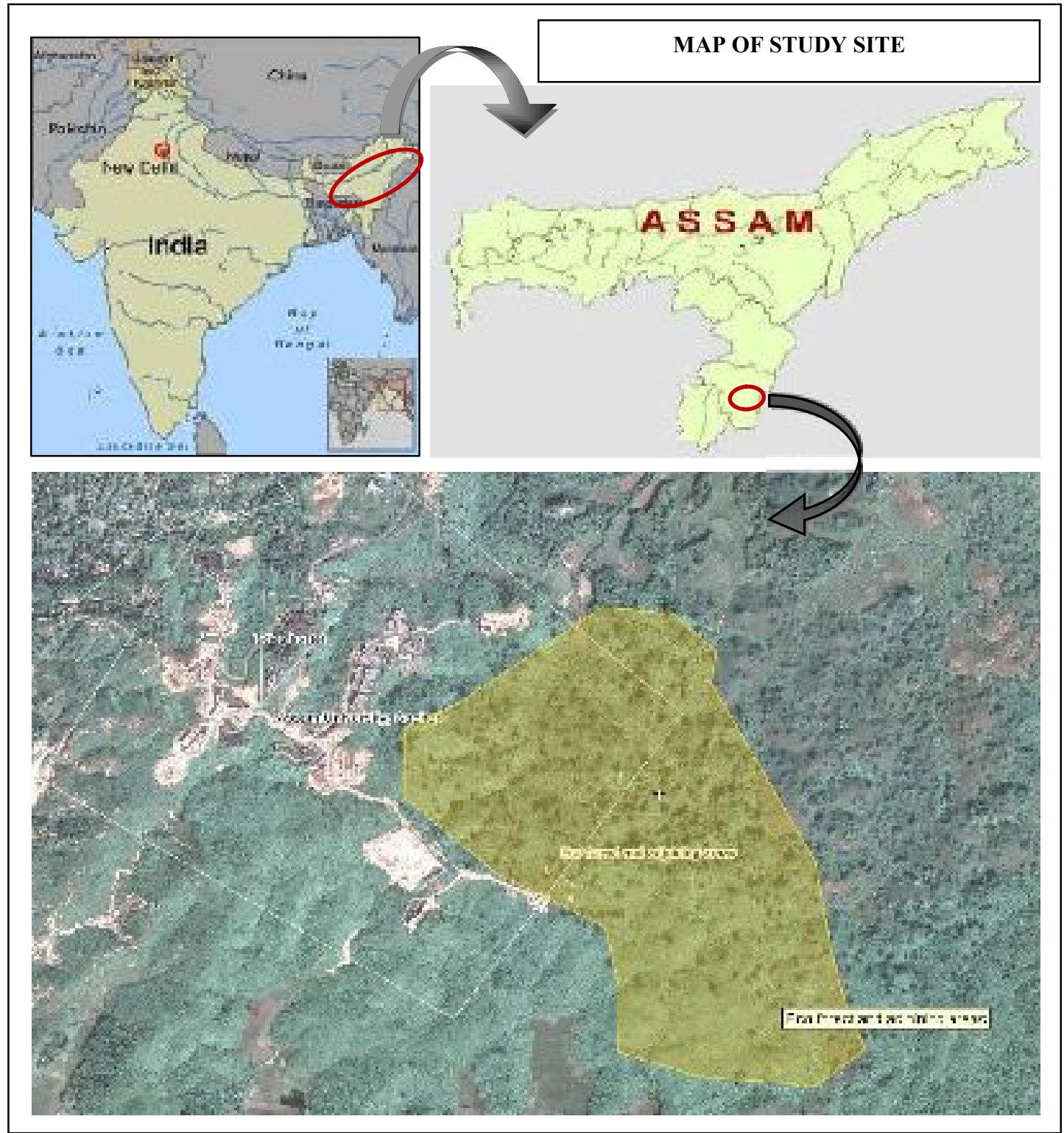

Figure 1. Map of the study site (AUS Campus) and adjoining areas.

Garden (TG), Natural Forest (NF) and Degraded Forest (DF), based on the major habitat characteristics, vegetation and dominant species (Tab. 1.). Line transects were laid down in each of these habitat types and mammalian fauna which were found along these transects were recorded by direct sightings and indirect evidences (Varman and Sukumar, 1995). The study was carried out from May, 2006 to June, 2007. The identification of the species recorded was done with the help of standard 
K. Mazumdar, R. Soud and A. Gupta /Our Nature (2011) 9:119-127

literature (Choudhury, 1995; Choudhury 1997; Menon, 2003). Secondary information was also collected from the villagers residing around the university campus and also from the local hunters regarding the presence/absence of the mammalian species in the study area.

\section{Results}

A total of 19 species of mammals belonging to 8 orders and 16 families were recorded during this study from the degraded forest habitats around the Assam University Campus (Tab. 2). Among them the order Primates, Carnivora and Chiroptera are the most diverse having 5 species each. Among all recorded species, 6 are included in the Schedule-I and another 7 species in the Schedule II of the Indian Wildlife (Protection) Act, 1972 (IWPA). Of these, $16 \%$ belongs to the EN, $5 \%$ to VU and $79 \%$ belongs to least concern (LC) species according to the IUCN category.

\section{Significant records}

The conservation status of each species encountered during the study is briefly reviewed. The significant results found are discussed below. Four species of primates are recorded so far in the area.

\section{Capped Langur Trachypithecus pileatus (Blyth, 1834)}

Capped langur is distributed in the entire state of Assam up to an elevation of $c .1500$ m. Choudhury (1997) referred to it as the subspecies Trachypithecus pileatus pileatus. This species was sighted twice during the study period near the village home-gardens adjoining the forest areas (Fig. 2). Exact status of this species in the valley is not known till date. Human-wildlife conflict is the main concern over the conservation of this species.

\section{Phayre's Leaf Monkey Trachypithecus phayrei (Blyth, 1847)}

Phayre's leaf monkey is known to occur in three states of North East India, viz., Assam (Barak valley), Tripura and Mizoram. Only 129 individuals of this IWPA Schedule- I species have so far been recorded in the state of Assam (Bose, 2002). About 47 individuals were recorded from the forests of Assam University Campus and nearby areas (Fig. 3).

\section{Western Hoolock Gibbon Hoolock hoolock (Harlan, 1834)}

One pair is present in the forest adjoining the Dargakona tea estate (Fig. 4). This forest patch also extends up to the Derby tea estate towards its south.

\section{Indian Muntjac Muntiacus muntjak (Zimmermann, 1780)}

Muntjac is extensively hunted by the local hunters for meat and skin and is often sold in the local village markets. It is also severely affected by anthropogenic activities such as clearing of forests.

\section{Jungle Cat Felis chaus}

(Schreber, 1777)

Found in the AUS-forest and other secondary forest habitats. Retaliatory killing by villagers against poultry predation comprises the major threat.

\section{Common Palm Civet Paradoxurus hermaphroditus (Pallas, 1777)}

Often found predating upon the poultry of the villagers. Retaliatory killing is the main threat to this species (Fig. 5). 
K. Mazumdar, R. Soud and A. Gupta /Our Nature (2011) 9:119-127

Table 1. Habitat types in the study area

\begin{tabular}{|c|c|c|}
\hline Patch title & Patch details & Information source \\
\hline$\overline{\text { Open forest (OF) }}$ & $\begin{array}{l}\text { Highly disturbed patch with different species of herbs, shrubs and } \\
\text { other secondary vegetation. }\end{array}$ & Dutta et al. (1998) \\
\hline Tea garden $(\mathrm{TG})$ & $\begin{array}{l}\text { Predominance of tea bushes along with shade trees. Extensive use of } \\
\text { pesticides is a major threat affecting the whole patch. }\end{array}$ & Personal observation \\
\hline $\begin{array}{l}\text { Natural forest } \\
\text { (Eco-Forest) (NF) }\end{array}$ & $\begin{array}{l}\text { Mature forest, slightly disturbed by anthropogenic activity. } \\
\text { Disturbance in the vegetation has resulted in the growth of early } \\
\text { successional plants. }\end{array}$ & Dutta et al. (1998) \\
\hline $\begin{array}{l}\text { Degraded forest } \\
\text { (DF) }\end{array}$ & $\begin{array}{l}\text { Highly disturbed patches around human habitation. Abundance of } \\
\text { planted tree species. }\end{array}$ & Dutta et al. (1998) \\
\hline
\end{tabular}

Table 2. Checklist of mammalian fauna of Assam University campus, Silchar.

\begin{tabular}{|c|c|c|c|c|}
\hline Species & Scientific name & Occurrence & $\begin{array}{l}\text { IUCN } \\
\text { Status }\end{array}$ & WPA status/ Remarks \\
\hline \multicolumn{5}{|l|}{ Order: PRIMATES } \\
\hline \multicolumn{5}{|l|}{ Family: Cercopithecidae } \\
\hline Rhesus Macaque & $\begin{array}{l}\text { Macaca mulatta } \\
\text { (Zimmermann, 1780) }\end{array}$ & $\begin{array}{l}\text { OF, TG, NF, } \\
\text { DF }\end{array}$ & $\mathrm{LC}$ & $\begin{array}{l}\text { WPA-II, fairly common in } \\
\text { the study site, close } \\
\text { interactions with human } \\
\text { habitats. }\end{array}$ \\
\hline Capped Langur & $\begin{array}{l}\text { Trachypithecus pileatus } \\
\text { (Blyth, 1834) }\end{array}$ & $\mathrm{NF}, \mathrm{DF}$ & $\mathrm{EN}$ & $\begin{array}{l}\text { WPA-I, Its recorded in the } \\
\text { southern and eastern part of } \\
\text { the Assam University }\end{array}$ \\
\hline Phayre's Leaf Monkey & $\begin{array}{l}\text { Trachypithecus phayrei } \\
\text { (Blyth, 1847) }\end{array}$ & NF, DF, TG & $\mathrm{EN}$ & $\begin{array}{l}\text { WPA-I, all together } 3 \text { troops } \\
\text { and } 1 \text { all-male -band is } \\
\text { recorded along with one new } \\
\text { distribution range behind } \\
\text { Jalenga Tea estate in a } \\
\text { Jayantia village. }\end{array}$ \\
\hline \multicolumn{5}{|l|}{ Family: Hylobatidae } \\
\hline Western Hoolock Gibbon & $\begin{array}{l}\text { Hoolock hoolock (Harlan, } \\
\text { 1834) }\end{array}$ & NF & $\mathrm{EN}$ & $\begin{array}{l}\text { WPA-I, One pair sometimes } \\
\text { visits the forest adjoining to } \\
\text { the Durgakona tea estate. }\end{array}$ \\
\hline \multicolumn{5}{|l|}{ Order: ARTIODACTYLA } \\
\hline \multicolumn{5}{|l|}{ Family: Cervidae } \\
\hline Indian Muntjac & $\begin{array}{l}\text { Muntiacus muntjak } \\
\text { (Zimmermann, 1780) }\end{array}$ & NF & $\mathrm{LC}$ & $\begin{array}{l}W P A-I I I \text {, Hunted by the local } \\
\text { hunters for meat and skin. }\end{array}$ \\
\hline \multicolumn{5}{|l|}{ Family: Suidae } \\
\hline Wild Pig/ Wild Boar & Sus scrofa (Linnaeus, 1758) & NF & $\mathrm{LC}$ & $\begin{array}{l}W P A-I I I, \text { Sometime raid crop } \\
\text { and vegetables in the nearby } \\
\text { village home gardens. }\end{array}$ \\
\hline \multicolumn{5}{|l|}{ Order: CARNIVORA } \\
\hline Indian Fox/Bengal Fox & $\begin{array}{l}\text { Vulpes bengalensis (Shaw, } \\
1800 \text { ) }\end{array}$ & $\mathrm{DF}$ & $\mathrm{LC}$ & $\begin{array}{l}W P A-I I \text {, Common in the eco- } \\
\text { forest and nearby villages. }\end{array}$ \\
\hline \multicolumn{5}{|l|}{ Family: Felidae } \\
\hline Jungle Cat & Felis chaus (Schreber, 1777) & NF, DF & $\mathrm{LC}$ & $\begin{array}{l}W P A-I I, \text { Found in the Eco- } \\
\text { forest and other secondary } \\
\text { forest habitats. Retaliatory } \\
\text { killed by villagers against } \\
\text { poultry predation. }\end{array}$ \\
\hline
\end{tabular}


K. Mazumdar, R. Soud and A. Gupta /Our Nature (2011) 9:119-127

Table 2-Contd...

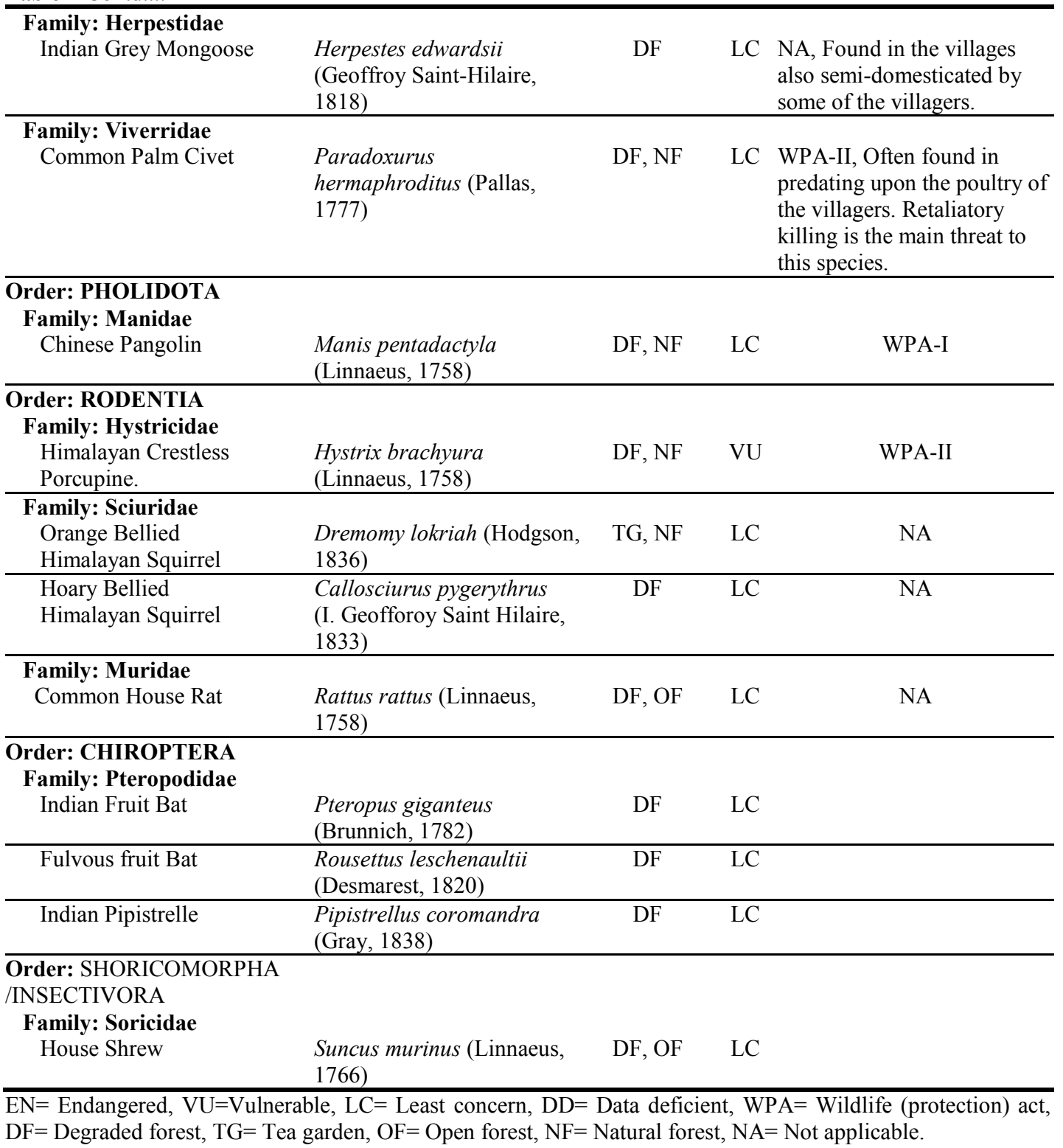

Chinese Pangolin Manis pentadactyla (Linnaeus, 1758)

Among the mammals of Assam University this species is facing the most severe threat from the local people and hunters (Fig. 6). Very often it is captured from the forests of the study area for the purpose of consumption of its meat and medicinal use of its various parts.

\section{Himalayan Crestless Porcupine Hystrix brachyura (Linnaeus, 1758)}

This nocturnal species is occasionally found in the study area. It is often regarded as a 
K. Mazumdar, R. Soud and A. Gupta /Our Nature (2011) 9:119-127

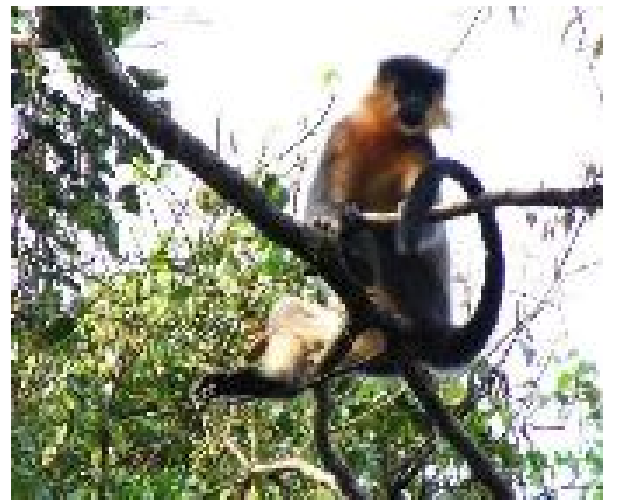

Figure 2. Capped Langur Trachypithecus pileatus (Photo: K. Mazumdar)

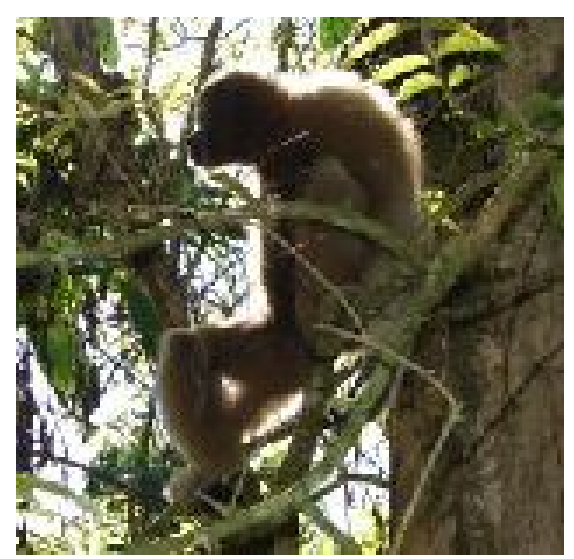

Figure 4. Western Hoolock Gibbon Hoolock hoolock (Photo: R. Soud)

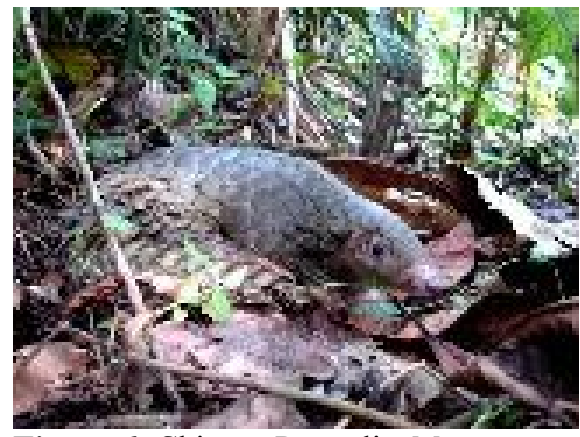

Figure 6. Chinese Pangolin Manis pentadactyla (Photo: R. Soud)

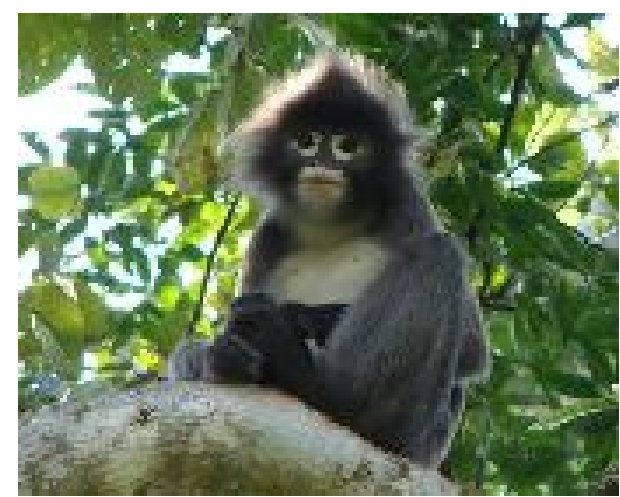

Figure 3. Phayre's Leaf Langur

Trachypithecus phayrei (Photo: K. Mazumdar)

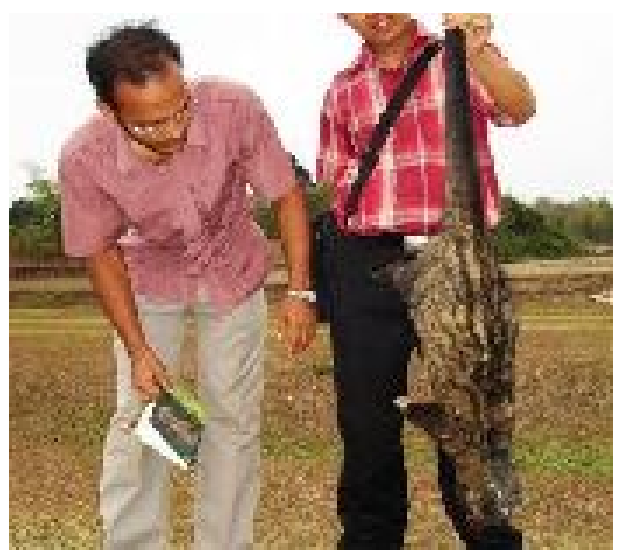

Figure 5. Common Palm Civet Paradoxurus hermaphrodites killed by villagers because of retaliatory causes (Photo: R. Soud)

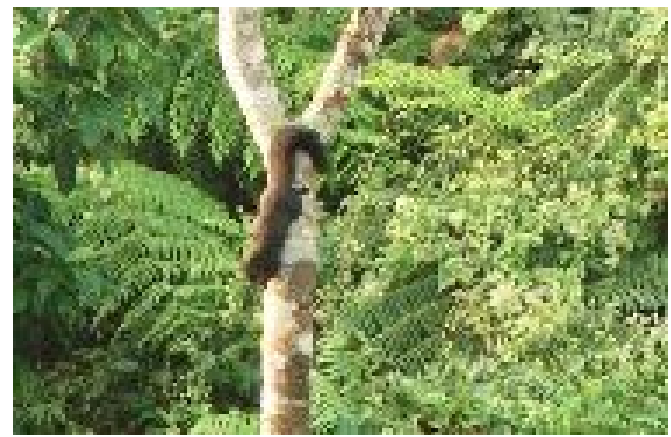

Figure 7. Orange Bellied Himalayan Squirrel Dremomy lokriah (Photo: K. Mazumdar) 


\section{K. Mazumdar, R. Soud and A. Gupta /Our Nature (2011) 9:119-127}

crop raider in the surrounding villages of eco-forest and also hunted for its meat.

\section{Orange-Bellied Himalayan Squirrel Dremomys lokriah (Hodgson, 1836)}

On $13^{\text {th }}$ March, 2006, during the course of a field study trip to the Ecoforest we had sighted an Orange-Bellied Himalayan Squirrel Dremomys lokriah (Fig. 7) in the outskirts of the western boundary of the AUS forest bordering Dargakona tea estate (Soud et al., 2010).

\section{Discussion}

The mammalian species still surviving in this area are facing an acute problem of habitat fragmentation. Fragmentation of habitat is considered to be the most significant threat to the survival of mammals, particularly the primates in Northeast India (Srivastava, 2006). Though certain species can survive in disturbed habitats, the long-term consequences on their reproduction and survival are not known. Since forest loss is the principal threat to the mammals and other fauna in this area, habitat protection has to be given highest conservation priority. Primates, which are one of the most adaptive mammalian groups, are also finding it difficult to persist in the study area. Strict prevention of further extraction of fuel wood and indiscriminate collection of NTFPs by the village people and illegal cutting of timber by outsiders, therefore, needs to be implemented with priority. Canopy bridges or corridors may be established to link up the small fragmented pockets of habitat. This could help in the conservation of the scattered troops of monkeys and reduce man-animal conflict with species like the Rhesus macaque. Conservation education could also be very effective for making people understand the value of wildlife. The tea garden labour communities residing in this area have a rich tradition of offering community protection to plants and animals through small sacred groves called 'thans' (Gupta and Guha, 2002). They could, therefore, be encouraged to further this tradition to conserve the rich biodiversity of their land.

\section{Acknowledgements}

The authors express their gratitude to Prof. A.K. Das and other faculties of the Department of Ecology and Environmental Science, Assam University, Silchar. We also thank to Mr. P.J. Borah, WWF, India (WAL) for his help during the preparation of map and our field guide, Mr. J. Bhar.

\section{References}

Bose, J. and P.C. Bhattacharjee 2002. Behavioural profile of a troop of Phayre's leaf monkey (Trachypithecus phayrei) in a fragmented and disturbed habitat, northeast India. (abstract) XIX Congress of the International Primatological Society. Beijing, China, 0287.

Choudhury, A. 1995. Mammals of southern districts of Assam. Cheetal 34(2): 10-17.

Choudhury, A. 1997. Checklist of the Mammals of Assam. Gibbon Books and Assam Science Technology and Environment Council, Guwahati. $103 p$.

Choudhury, A. 2006. The status of endangered species of North-east India. J. Bomb. Nat. Hist. Soc. 103(2-3): 157-167.

Das, T. and A.K. Das 2005. Inventorying plant biodiversity in homegardens: A case study in Barak valley, Assam, North East India. Current Science 89(1): 155-163.

Dutta, B.K., A. Gupta and A.K. Das 1998. Assam University Campus (Silchar) ecology and biodiversity. Assam University, Silchar. 19p.

Gupta, A. and K. Guha 2002. Tradition and conservation in Northeastern India: An ethical analysis. Eubios Journal of Asian and International Bioethics 12: 15-18. 
K. Mazumdar, R. Soud and A. Gupta /Our Nature (2011) 9:119-127

Menon, V. 2003. A field guide to Indian mammals. Dorling Kindersley (India) Pvt. Ltd. 201p.

Nameer, O.P. 2000. Checklist of Indian mammals. Kerela Forest Department and Kerela Agricultural University. 90p.

Nameer, O.P. 2008. Checklist of Indian mammals. Revised and updated, 2008. ZOOS' Print. Journal 23: 8, (RNI 9: 11).

Soud, R., K. Mazumdar and A. Gupta 2010. Sighting record of the Orange-Bellied Himalayan Squirrel Dremomys lokriah Hodgson, 1836 in Cachar district, Assam. NeBIO. 1(3): 14-15.
Srinivasulu, C., B. Srinivasulu, A. Rajesh, C.A.N Rao and V. Nagulu 2004. Non-volant small mammals of Kasu Brahmananda Reddy National park, Andhra Pradesh. ZOOS' Print Journal 19(6): 1495-1497.

Srivastava, A. 2006. Conservation of threatened Primates of Northeast India. Primate Conservation 20: 107-113.

Varman, K.S. and R. Sukumar 1995. The line transect method for estimating densities of large mammals in a tropical deciduous forest: An evaluation of models and field experiments. J. Biosci. 20(2): 273-287. 